\title{
Bacteriological Profile of Patients with AECOPD- Hospital Based Study
}

\author{
M.F. Aleemullah ${ }^{1 *}$, V.Krishnamurthy ${ }^{2}$, M.Harish $^{3}$ and C.Arshad Akeel ${ }^{4}$ \\ ${ }^{1}$ Department of Microbiology, Madha Medical College and Research Institute, Chennai, India \\ ${ }^{2}$ Senior Consultant, Rheumatologist, Chennai Meenakshi Multi Speciality hospital Ltd, India \\ ${ }^{3}$ Respiratory \& Chest Physician, Chennai Meenakshi Multi Speciality Hospital Ltd, India \\ ${ }^{4}$ Senior Consultant physician, Apollo Hospital, Chennai, India \\ *Corresponding author
}

\begin{abstract}
A B S T R A C T
Keywords

Haemophilus influenza,

Chronic

obstructive

pulmonary

disease,

Tuberculosis.

Article Info

Accepted:

09 March 2016

Available Online:

10 April 2016

COPD is defined as a disease state characterized by airflow limitation that is not fully reversible. The airflow limitation is usually both progressive and associated with an abnormal inflammatory response of the lungs to noxious particles or gases. Exacerbations, mostly of bacterial, are a frequent cause of morbidity in COPD patients. A total of 148 sputum samples were collected from AECOPD patients. All collected sputum samples were subjected to standard microbiological procedures. Out of 148 sputum samples, growth of pathogenic organisms was obtained in 109 $(73.65 \%)$ sputum samples. Gram negative organisms were isolated predominantly 68(62.39\%). While Gram positive organisms accounted for 41(37.61\%). Haemophilus influenzae 38(34.86) was the predominant bacteria isolated followed by Streptococcus pneumonia 25(22.94). Eight patients had positive mycobacterial sputum culture on Lowenstien Jensen medium. Majority of isolates were sensitive to piperacillin/ tazobactum followed by amikacin. $H$. influenzae was the commonest bacterium isolated predominantly. Piperacillin/ tazobactum and amikacin were the most active antibacterial agents in our study. It is essential to screen for sputum AFB in endemic areas of tuberculosis.
\end{abstract}

\section{Introduction}

Chronic obstructive pulmonary disease (COPD) is characterized by a usually progressive decline in lung function and worsening of breathlessness, exercise capacity and impairment of quality of life with time.1 Exacerbations are episodes of acute worsening of clinical condition in patients with COPD. An episode of acute exacerbation of COPD (AECOPD) was defined as, "an acute event characterized by worsening of the patient's respiratory symptoms that is beyond normal day-to-day variations and leads to a change in medication". (GOLD, 2014) One of the earliest studies to know the prevalence of COPD in India was carried out by Wig et al in rural Delhi (Wig et al., 1964). COPD is the fourth leading cause of death in the world and will become the third leading cause of death worldwide by 2020 . Four to ten percent adult male population of India and 3.5 to $6.5 \%$ population in Asia pacific countries suffer from this disease (Patel et al., 2015). 
Exacerbations can be of bacterial, viral or non-infectious etiology, and a significant proportion can be multi-factorial (Papi et al., 2006). Cigarette smoking or inhalation of dust or fumes are important contributing factors ( Jindal et al., 1983) The prevalence of AECOPD varying from $1 \%$ in urban nonsmoker to $21 \%$ in rural smokers and mortality rate of $24 \%$ if the patient required ICU admission. This mortality rate increased to $30 \%$ if the patient was above 65 years (Sharan, 2015) It is estimated that bacterial infections are responsible for more than $40 \%$ of all exacerbations in India (Chawla, 2008).

In previous studies, the predominant organisms dur ing acute infective exacerbations were believed to be Streptococcus pneumoniae, nontypable Haemophilus influenzae, and to some extent Moraxella catarrhalis (Murphy, 1987). However, these studies were based on heterogeneous patient groups and the results are difficult to interpret because of methodologic differences related to the use of either expectorated sputum or specimens obtained by bronchoscopy (Monso, 1995). Bacterial flora of AECOPD is changing from usual pathogen. The choice of the antibiotic should be based on the local bacterial resistance pattern. Therefore the knowledge of bacterial flora of patients of AECOPD of that geographical area is required (Patel, 2015).

Hence we aimed at determining the bacteria which is predominantly responsible for AECOPD. The study was also done to assess their antimicrobial susceptibility pattern of these isolates so that we can design a proper antibiotic regimen which will have a beneficial effect on the morbidity and mortality of the disease.

\section{Materials and Methods}

This is a prospective, observational study in which a total of 148 sputum samples were collected from AECOPD patients who attended the Inpatient and Outpatient Departments of Chennai Meenakshi Multispeciality Hospital, Luz Chruch Road, Chennai-600 004, India over a period of one year from January 2014 until December 2014.

\section{Inclusion Criteria}

Patients were diagnosed by the clinician concerned depending upon the presence of two of the following symptoms:

Increased cough

Increased purulence and/or volume of expectorations

Increased severity of dyspnoea.

\section{Exclusion Criteria}

Previous diagnosis of bronchial asthma, cystic fibrosis, or bronchiectasis

Diagnosis of neoplasia

Clinical-radiologic evidence of pneumonia

Any type of antibiotic treatment received over the 5 days prior to sampling the sputum for culture.

\section{Specimens}

Early morning expectorated sputum samples were collected in wide mouth sterile containers after giving appropriate instructions for all patients. The quality of the sputum was assessed by both macroscopic and microscopic examination. All sputum samples were subjected to Gram staining and reported based on Bartlett's grading system (Koneman et al., 2006). All unsuitable specimens were discarded and a 
repeat specimen was collected. The suitable sputum samples were inoculated onto Mac Conkey's agar, chocolate agar and two blood agar plates. On one blood agar streaking with Staphylococci was done to facilitate growth of Haemophilus influenzae. All the plates were incubated at $37^{\circ} \mathrm{C}$ for 24 hours in 7-10 \% CO2 concentration. Acid fast staining and culture for Mycobacterium species onto Lowenstein-Jensen medium after decontamination of sputum specimens were performed according to standard procedures (Murray et al.,2006)

\section{Antibiotic Sensitivity Testing}

Antimicrobial susceptibility of the isolates was determined against the following antibacterial agents by Kirby Bauer disk diffusion method on Muller Hinton agar plates according to Clinical and Laboratory Standard Institute guidelines (CLSI, 2011).

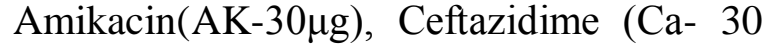
$\mu \mathrm{g})$, Cefotaxime (Ce-30 $\mu \mathrm{g})$, Ciprofloxacin

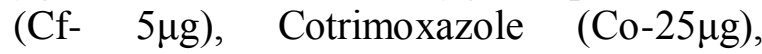
Gentamycin (G-10 $\mu \mathrm{g}), \quad$ PiperacillinTazobactum(Pt- $\quad 100 / 10 \mu \mathrm{g}), \quad$ Imipenem[I $10 \mu \mathrm{g}]$, Cephoxitin $(\mathrm{Cn}-30 \mu \mathrm{g})$, Clindamycin $(\mathrm{Cd}-2 \mu \mathrm{g}), \quad$ Erythromycin $\quad(\mathrm{E}-15 \mu \mathrm{g})$, chloramphenicol $(30 \mu \mathrm{g})$, Penicillin (P-10 units), Linezolid(Le-30 $\mu \mathrm{g}), \quad$ Vancomycin (Va-30 $\mu \mathrm{g}$ ) (Hi Media, Mumbai).

All the analysis was performed using simple percentage method.

\section{Results and Discussion}

A total of 148 cases were included in the present study $124(83.79 \%)$ males and 24 (16.21\%) females having mean age 54.7 years. All males were smokers while all females though non-smokers, but exposed to biomass fuel. Growth of pathogenic organisms was obtained in $109(73.65 \%)$ sputum samples. It was observed that purulent sputum gave better isolation of pathogens than mucoid sputum. (Table1) Gram negative organisms were isolated predominantly 68 (62.39\%). While Gram positive organisms accounted for 41 $(37.61 \%)$.

Haemophilus influenzae 38 (34.86) was the predominant bacteria isolated followed by Streptococcus pneumonia 25 (22.94), Klebsiella pneumonia 11 (10.09\%), Pseudomonas aeruginosa $19(17.43 \%)$ and Staphylococcus aureus 8 (7.34\%). A total of eight patients had positive mycobacterial sputum culture. Out eight patients with positive mycobacterial growth, M. tuberculosis (MTB) was identified in five $(4.59 \%)$ patients whereas atypical mycobacterium was identified in three $(2.75 \%)$ patients. All three atypical mycobacteria were identified as $M$. chelonae.

Mixed infections were identified in $17(15.60 \%)$ sputum samples. Only one patient had positive growth on both routine culture media (Pseudomonas aeruginosa) and Lowenstein Jensen medium (Mycobacterium tuberculosis).

Antibiotic sensitivity pattern to all organisms is shown in Table 2. Majority of isolates were sensitive to piperacillin/ tazobactum followed by amikacin irrespective of gram positive or negative organisms. All gram negative bacteria were susceptible to Imipenam except Pseudomonas aeruginosa, where four isolates were resistant. All gram positive bacteria were susceptible to Vancomycin and Linezolid uniformly. Chronic obstructive pulmonary disease (COPD) is a leading cause of mortality worldwide and is associated with an important morbidity related in large part to acute COPD exacerbations (AECOPD) (Ai-Ping, 2005). 
Table.1 Demographic Data of Patients with COPD and Physical Characteristics of Sputum Samples

\begin{tabular}{|c|c|}
\hline Age & Mean 54.7 \\
\hline \multicolumn{2}{|c|}{ Sex } \\
\hline Male & $124(83.79 \%)$ \\
\hline Female & $24(16.21 \%)$ \\
\hline \multicolumn{2}{|c|}{ Smoking status } \\
\hline Smokers & $42(28.38 \%)$ \\
\hline Ex-smokers & $77(52.02 \%)$ \\
\hline Non-smokers & $29(19.59 \%)$ \\
\hline Biomass fuel & $17(11.49 \%)$ \\
\hline \multicolumn{2}{|c|}{ Physical characteristics of sputum } \\
\hline Purulent samples & $112 / 148$ \\
\hline Mucoid samples & $36 / 148$ \\
\hline \multicolumn{2}{|c|}{ Significant growth of pathogen } \\
\hline Purulent samples & $94 / 112(83.93 \%)$ \\
\hline Mucoid samples & $15 / 36(41.67 \%)$ \\
\hline
\end{tabular}

Table.2 Antibiotic Sensitivity Pattern of Bacteria

\begin{tabular}{|c|c|c|c|c|c|c|c|c|c|c|c|}
\hline Isolate & $\mathrm{AK}$ & $\mathrm{G}$ & I & PIT & $\mathrm{E}$ & $\mathrm{CiP}$ & $\operatorname{mox}$ & $\begin{array}{l}\text { Cefata } \\
\text { xi }\end{array}$ & $\begin{array}{l}\text { Cefuroxi } \\
\text { me }\end{array}$ & VA & $\mathrm{LZ}$ \\
\hline $\begin{array}{l}\text { H.influenzae } \\
\text { (38) }\end{array}$ & $\begin{array}{l}35 \\
(92.11 \\
\%)\end{array}$ & $\begin{array}{l}15 \\
(59.47 \\
\%)\end{array}$ & $\begin{array}{l}38 \\
(100 \% \\
)\end{array}$ & $\begin{array}{l}36 \\
(94.74 \\
\%)\end{array}$ & $\begin{array}{l}19 \\
(50 \%)\end{array}$ & $\begin{array}{l}17 \\
(44.74 \\
\%)\end{array}$ & $\begin{array}{l}31 \\
(81.58 \\
\%)\end{array}$ & $\begin{array}{l}19 \\
(50 \%)\end{array}$ & $\begin{array}{l}11 \\
(28.95 \% \\
)\end{array}$ & NT & NT \\
\hline $\begin{array}{l}\text { Streptococc } \\
\text { us } \\
\text { Pneumoniae } \\
\text { (25) }\end{array}$ & $\begin{array}{l}21 \\
(84 \%)\end{array}$ & $\begin{array}{l}19 \\
(76 \%)\end{array}$ & NT & $\begin{array}{l}22 \\
(88 \%)\end{array}$ & $\begin{array}{l}15(60 \\
\%)\end{array}$ & $\begin{array}{l}13 \\
(52 \%)\end{array}$ & $\begin{array}{l}15 \\
(60 \%)\end{array}$ & $\begin{array}{l}11 \\
(44 \%)\end{array}$ & $\begin{array}{l}15 \\
(60 \%)\end{array}$ & $\begin{array}{l}25 \\
(100 \\
\%)\end{array}$ & $\begin{array}{l}25 \\
(100 \\
\%)\end{array}$ \\
\hline $\begin{array}{l}\text { Pseudomon } \\
\text { as } \\
\text { aeruginosa( } \\
\text { 19) }\end{array}$ & $\begin{array}{l}15 \\
(78.95 \\
\%)\end{array}$ & $\begin{array}{l}11 \\
(57.89 \\
\%)\end{array}$ & $\begin{array}{l}16 \\
(84.21 \\
\%)\end{array}$ & $\begin{array}{l}16 \\
(84.21 \\
\%)\end{array}$ & NT & $\begin{array}{l}9 \\
(47.37 \\
\%)\end{array}$ & $\begin{array}{l}10 \\
(52.63 \\
\%)\end{array}$ & $\begin{array}{l}8 \\
(42.11 \\
\%)\end{array}$ & $\begin{array}{l}9 \\
(47.37 \% \\
)\end{array}$ & NT & NT \\
\hline $\begin{array}{l}\text { Klebsiella } \\
\text { Pneumoniae } \\
\text { (11) }\end{array}$ & $\begin{array}{l}9(81.82 \\
\%)\end{array}$ & $\begin{array}{l}5 \\
(45.45 \\
\%)\end{array}$ & $\begin{array}{l}11 \\
(100 \\
\%)\end{array}$ & $\begin{array}{l}11 \\
(100 \\
\%)\end{array}$ & NT & $\begin{array}{l}4 \\
(36.36 \\
\%)\end{array}$ & $\begin{array}{l}4 \\
(36.56 \\
\%)\end{array}$ & $\begin{array}{l}6 \\
(54.55 \\
\%)\end{array}$ & $\begin{array}{l}2 \\
(18.18 \%\end{array}$ & NT & NT \\
\hline $\begin{array}{l}\text { Staphylococ } \\
\text { cus aureus } \\
\text { (8) }\end{array}$ & $6(75 \%)$ & $\begin{array}{l}2 \\
(25 \%)\end{array}$ & NT & $\begin{array}{l}7(87.5 \\
\%)\end{array}$ & $\begin{array}{l}2 \\
(25 \%)\end{array}$ & $\begin{array}{l}4 \\
(50 \%)\end{array}$ & $\begin{array}{l}6 \\
(75 \%)\end{array}$ & $\begin{array}{l}2 \\
(25 \%)\end{array}$ & $\begin{array}{l}1 \\
(12.5 \%)\end{array}$ & $\begin{array}{l}8 \\
(100 \\
\%)\end{array}$ & $\begin{array}{l}8 \\
(100 \\
\%)\end{array}$ \\
\hline
\end{tabular}

Sputum culture was positive in $73.65 \%$ of patients with AECOPD which was higher as compare to other studies. According to the study conducted by Patel et al. (2015) Sputum culture was positive in $82 \%$ of patients with AECOPD which was higher as compare to other studies. (Ko et al., 2008)

This difference may be because of the fact that culture positivity depends on nature of 
sputum, time of collection sputum and previous antibiotic use. Males were affected more than females because they were more involved in smoking and therefore more chance of inhalation and increased environmental exposure or temperature variation. (Raza et al., 2013)

All females though non-smokers, but had constant exposure to biomass fuel. Majority of females encountered in our study are from sub urban areas. Worldwide, about $50 \%$ of all households and $90 \%$ of rural households use biomass fuel (wood, charcoal, other vegetable matter, and animal dung) and coal as their main source of domestic energy. About 50\% of deaths from COPD in developing countries are attributable to biomass smoke, of which about $75 \%$ are of women. (Lopez et al., 2006). More than $80 \%$ of homes in China, India, and sub-Saharan Africa use biomass fuel for cooking. (Reddy et al., 1996)

Gram negative organisms were isolated predominantly 68 (62.39\%). While Gram positive organisms accounted for 41 $(37.61 \%)$. According to the study conducted by Dalia et al (2016), Gram positive bacteria represented $80 \%$ of isolates, while Gram negative bacteria represent the remaining $20 \%$.However other studies reported the predominance of Gram negative bacteria. (Viswambhar et al., 2013 and Madhavi et al, 2012) In our study Haemophilus influenzae $38(34.86 \%)$ was the most common pathogen followed by Streptococcus pneumonia $25(22.94 \%)$. This finding is contrary to other studies reported from by Chawla et al. (2008) who had found Pseudomonas aeruginosa while Madhavi et al. (2012) had found Klebsiella pneumonia as the most common organism. However, Groenewegan et al. (2003)reported Hemophilus influenza $(45 \%)$ as most frequent organism followed by streptococcus pneumonia (27\%).
Screening for TB in patients with AECOPD is essential in this locality with a high background prevalence of TB infection as systemic steroid is often prescribed for AECOPD in order to speed up recovery of airway function and reduce hospital length of stay. (Niewoehner et al., 1999) In our study M. tuberculosis (MTB) was identified in five $(4.59 \%)$ patients whereas atypical mycobacterium was identified in three $(2.75 \%)$ patients. Atypical mycobacterial growth in sputum of these patients might be due to colonization rather than genuine infection. Nevertheless, careful follow-up with repeated sputum cultures and radiological examination is needed in these patients.

In the present study, amikacin, piperacillintazobactum and imipenem showed good response among Gram negative bacilli. Ciprofloxacin and cephalosporins showed decreased sensitivity. All strains of Gram positive cocci were sensitive to vancomycin and linezolide. However, vancomycinintermediate and vancomycin resistant $S$. aureus (VISA and VRSA) strains have been reported recently from various parts of the country. (Menezes et al., 2008) According to the study conducted by Patel et al. (2015) piperacilline/tazobactum was the most effective antibiotic against all organisms (gram positive and gram negative) which is in agreement with the present study.

In conclusion, $H$. influenzae was the commonest bacterium isolated predominantly. Piperacillin/ tazobactum should be the first choice empirical antibiotic. It is essential to screen for sputum Acid Fast Staining in endemic areas of tuberculosis. Further studies are required to formulate an antibiotic policy at regular intervals. 


\section{References}

Ai-Ping, C., Lee, K.H., Lim, T.K. 2005. Inhospital and 5-year mortality of patients treated in the ICU for acute exacerbation of COPD: a retrospective study. Chest, 128(2): 518-524.

Chawla, K., Mukhopadhay, C., Majumdar, M., Bairy, I. 2008. Bacteriological profile and their antibiogram from cases of acute exacerbations of chronic obstructive pulmonary disease: A hospital based study. J. Clin. Diag. Res., 2: 612-616.

Clinical and laboratory standards institute. 2011. Performance standards for antimicrobial susceptibility testing.21st information supplement M100- S21.Wayne, PA, USA: Clinical and laboratory standards institute.

Dalia Saad ElFeky, Heba Mohammed Elmandory, Mohamed Galal, Mohamed Abdel Hakim. 2016. Sputum Bacteriology in Patients with Acute Exacerbation of Chronic Obstructive Pulmonary Disease. Int. J. Curr. Microbiol. App. Sci., 5(1): 289-305.

Global Initiative for Chronic Obstructive Lung Disease (GOLD). 2014. Global Strategy for the Diagnosis, Management and Prevention of Chronic Obstructive Lung Disease (Updated 2014).

Groenewegen, K.H., Schols, A.M., et al. 2003, 1964. Mortality and mortalityrelated factors after hospitalization for acute exacerbation of COPD. Chest, 124: 459-67, Ind. J. Chest Dis., 6: 183-94.

Jindal, S.K., Malik, S.K. 1983. Tobacco smoking and nonneoplastic respiratory diseases.In: Sanghv, D., Notani, P., editors Tobacco and
Health: The Indian Scene. Bombay: Tata Memorial Centre, 30.

Ko, F.W., Hui, D.S., Lai, C.K. 2008. Worldwide burden of COPD in highand low-income countries. Part III. Asia-Pacific studies. Int. J. Tuberc. Lung Dis., 12: 713-717.

Koneman, E.W., Allen, S.D., Janda, W.M., Schrekenberger, P.C. 2006. Color Atlas and Text book of Diagnostic Microbiology; 6th edn. Philadelphia: JB Lippencott.

Lopez, A.D., Mathers, C.D., Ezatti, M. 2006. Global burden of disease and risk factors. Washington, DC: World Bank.

Madhavi, S., Rama Rao, M.V., Janardhan Rao, R. 2012. Bacterial etiology of acute exacerbations of chronic obstructive pulmonary disease. $J$. Microbiol. Biotechnol. Res., 2(3): 440-44.

Menezes, G.A., Harish, B.N., Sujatha, S., Vinothini, K., Parija, S.C. 2008. Emergence of vancomycinintermediate Staphylococcus species in southern India. J. Med. Microbiol., 57: 911-2.

Monso, E., Ruiz, J., Rosell, A. 1995. Bacterial infection in chronic obstructive pulmonary disease. Am. J. Respir. Crit. Care Med., 152: 1316-208.

Murphy, T.F., Apicella, M.A. 1957. Nontypable Haemophilus influenzae: a review of clinical aspects, surface antigens, and the human immune response to infection. Rev. Infect. Dis., 9: 1-15.

Murray, P.R., Baron, E.J., Jorgensen, J.H., Pfaller, M.A., Yolken, R.H. 2003. Manual of clinical microbiology, 8th ed. Washington, DC, USA: ASM Press.

Niewoehner, D.E., Erbland, M.L., Deupree, R.H. 1999. Effect of systemic 
glucocorticoids on exacerbations of chronic obstructive pulmonary disease. Department of Veterans Affairs Cooperative Study Group. $N$. Engl. J. Med., 340: 1941-7.

Papi, A., Bellettato, C.M., Braccioni, F., Romagnoli, M., Casolari, P., Caramori, G., et al. 2006. Infections and airway inflammation in chronic obstructive pulmonary disease severe exacerbations. Am. J. Respir. Crit. Care Med., 173: 1114-21.

Patel, A.K., Luhadia, A.S., Luhadia, S.K. 2015. Sputum Bacteriology and Antibiotic Sensitivity Pattern of Patients Having Acute Exacerbation of COPD in India - A Preliminary Study. J. Pulm. Respir. Med., 5: 238. doi: 10.4172/2161-105X.1000238

Raza, M.Z., Ahmed, A., Ahmed, F., Ghani, A., Rizvi, N. 2013. Chronic obstructive pulmonary disease exacerbations: epidemiology and impact on patient's outcome. Int. J. Environ. Sci., 6(3): 1899-908.
T.B. 1996. Energy after Rio:prospects and challenges. New York, NY: UN.

Sharan, H. 2015. Aerobic Bacteriological Study of Acute Exacerbations of Chronic Obstructive Pulmonary Disease. J. Clin. Diag. Res., 9(8): DC10-DC12. doi:10.7860/JCDR/2015/14515.6367

Viswambhar, V., Vishnusharma, M., Harsha, D.S., Cholas, S., Sowjanya, Anupama, N. 2013. Gram negative bacterial pathogens and their sensitivity pattern in patients with acute exacerbation of chronic obstructive pulmonary disease. Res. J. Pharma. Biol. Chem. Sci., 4(2): 1549-59.

Wig, K.L., Guleria, J.S., Bhasin, R.C., Holmes, E., Jr, Vasudeva, Y.L. 1964 Singh H. Certain clinical and epidemiological patterns of chronic obstructive lung disease as seen in Northern

Reddy, A.K.N., Williams, R.H., Johansson,

\section{How to cite this article:}

M.F. Aleemullah, V. Krishnamurthy, M.Harish and C. Arshad Akeel. 2016. Bacteriological Profile of Patients with AECOPD- Hospital Based Study. Int.J.Curr.Microbiol.App.Sci. 5(4): 84-90. doi: http://dx.doi.org/10.20546/ijcmas.2016.504.012 